\title{
SOCIO EDUPRENEUR SEBAGAI UPAYA PENINGKATAN KUALITAS PENDIDIKAN DI INDONESIA
}

\author{
Hadi Ismanto \\ Progran Studi Kewirausahaan, Fakultas Ekonomi dan Bisnis, Universitas Muhammadiyah \\ Gresik \\ hadi_ismanto@umg.ac.id
}

\section{Vembri Aulia Rahmi}

Progran Studi Kewirausahaan, Fakultas Ekonomi dan Bisnis, Universitas Muhammadiyah Gresik vembriaulia@umg.ac.id

\begin{abstract}
Additional learning or tutoring is urgently needed to help improve learning but due to high costs, some communities, especially those in the middle to lower economic level, are unable to register their children to attend tutoring (additional tutoring).

The existence of Socioedupreneur is an alternative solution for those who do not have the cost to experience tutoring. Paying sincerely or not at all can alleviate them in terms of costs and can show the importance of education for the future and instill that all have the right to receive the same education. This research was conducted to determine the role of socio edupreneur in improving the quality of education.

The purpose of this study was to determine the role of socio edupreneur as an effort to improve the quality of education in Indonesia. The method used by researchers in this study uses qualitative research methods, this type of research is descriptive qualitative research, a case study approach that is an approach to study, explain or interpret a case. In essence, this study seeks to highlight a decision or set of decisions or set of decisions why the decision was taken, how it was implemented, and what the results were. This research intensively focuses on an object that is about how the role of socioedupreneur in improving the quality of education.
\end{abstract}

Keywords: Socio Education, Entrepreneurship, Role, Obstacles, Solution

\section{PENDAHULUAN}

Pendidikan adalah salah satu factor terpenting dalam pembentukan karakter seseorang, karena melalui pendidikan seorang individu akan belajar tentang akhlak, moral, normaserta nilai-nilai dalam masyarakat. Melalui pendidikan pula seseorang dapat memperoleh masa depan yang lebih baik serta penghidupan yang layak untuk mengangkat derajatnya. Kualitas pendidikan di Indonesia saat ini sangat memprihatinkan. Ini dibuktikan dengan data UNESCO (2013) tentang peringkat Indeks Pengembangan Manusia (Human Development Index), yaitu komposisi dari peringkat pencapaian pendidikan, kesehatan, dan penghasilan per kepala yang menunjukkan bahwa indeks pengembangan manusia Indonesia makin menurun. Indonesia menempati urutan ke -121 dari 185 negara.

Menurut survei Political and Economic Risk Consultant (PERC), kualitas pendidikan di Indonesia berada pada urutan ke-12 dari 12 negara di Asia. Posisi Indonesia berada di bawah Vietnam. Data yang dilaporkan The World Economic Forum Swedia (2000), Indonesia memiliki daya saing yang rendah, yaitu hanya menduduki urutan ke-37 dari 57 negara yang disurvei di dunia, dan masih menurut survey dari 
lembaga yang sama Indonesia hanya berpredikat sebagai follower bukan sebagai pemimpin teknologi dari 53 negara di dunia. Permasalahan utama pendidikan adalah mutu pendidikan khususnya yang berkaitan dengan ketersediaan pendidik dan tenaga kependidikan yang belum memadai baik secara kuantitas dan kualitas, maupun kesejahteraannya, sarana dan prasarana belajar yang belum cukup tersedia, bila tersedia belum di dayagunakan secara optimal, pendanaan pendidikan yang belum memadai untuk menunjang mutu pembelajaran, dan proses pembelajaran yang belum efektif dan efisien.

Guru memiliki peran utama untuk mempersiapkan dan menciptakan situasi belajar yang kondusif untuk mencapai pembentukan kompetensi peserta didik. Perbedaan mutu pendidikan yang ada di kota dan di desa yang berbeda baik dari segi pendidik, metode pembelajaran dan sebagainya. Di desa peran guru (tenaga pendidik) tidak hanya sebagai pengajar dan orang tua di sekolah seperti pada umumnya namun di desa semua menjadi tugas guru bahkan saat jam sekolah sudah selesaipun masih menjadi tanggungjawab guru. Peran yang seharusnya dilakukan oleh orang tua saat anaknya telah selesai jam pembelajaran di sekolah, namun pada praktiknya semua adalah tugas guru. Tugas yang sangat berat sebagai pendidik di desa dengan banyaknya jumlah siswa dan karakter peserta didik yang berbeda-beda membuat guru tidak maksimal dalam memberikan pelajaran, karena sebagian besar anak lambat dalam menerima pembelajaran.

Kurangnya kerjasama peran antara orangtua dan guru yang seharusnya bekerjasama dalam mendidik dan mengawasi anaknya dengan kata lain menjadi tanggungjawab guru saat anak berada disekolah dan menjadi tanggungjawab orang tua saat anak berada di rumah, sehingga terjadi kerjasama yang seimbang dan anak dapat terkontrol dengan baik dalambelajar. Pembelajarant tambahan atau bimbingan belajar sangat dibutuhkan untuk membantu meningkatkan pembelajaran namun karena biaya yang tinggi menyebabkan sebagian masyarakat terutama masyarakat dengan ekonomi menengah kebawah tidak mampu untuk mendaftarakan anaknya dalam mengikuti bimbingan belajar (bimbingan pelajaran tambahan).

Sosioedupreneur menjadi salah satu alternatif dalam mengatasi permasalahan tersebut, dimana saat ini sosioedupreneur sudah dilupakan karena pendapatan keuntungan yang minim. Namun hal tersebut sebenarnya sangat bermanfaat bagi mereka yang tidak memiliki biaya untuk merasakan bimbingan belajar. Dengan membayar seikhlasnya atau tidak sama sekali dapat meringankan mereka dalam masalah biaya dan dapat menunjukkan pentingnya pendidikan bagi masa depan dan menanamkan bahwa semua berhak mengenyam pendidikan yang sama.

Berdasarkan uraian di atas, maka peneliti berkeinginan melakukan penelitian tentang SosioEdupreneur Sebagai Upaya Peningkatan Kualitas Pendidikan di Indonesia.

\section{METODE PENELITIAN}

\section{Pendekatan dan Jenis Penelitian}

Metode yang digunakan oleh peneliti dalam penelitian ini menggunakan metode penelitian kualitatif. Metode penelitian kualitatif adalah metode penelitian yang digunakan untuk meneliti pada kondisi objek yang alamiah, dimana peneliti adalah instrumen kunci. Teknik pengumpulan data dilakukan secara triangulasi (gabungan), analisis data bersifat induktif, dan hasil penelitian kualitatif lebih menekankan makna daripada generalisasi (Sugiyono, 2015:1). Obyek dalam penelitian kualitatif adalah obyek yang alamiah, atau natural setting sehingga metode penelitian ini sering disebut sebagai metode naturalistik. Dengan menggunakan pendekatan kualitatif, memungkinkan peneliti untuk memperoleh data-data yang bersumber dari para pelaku Socio Edupreneur, Kepala sekolah serta wali murid, sehingga peneliti dapat menghasilkan data deskriptif sebagai salah satu acuan dalam penelitian ini.

\section{Sumber Data}

Jenis sumber data yang dikumpulkan dalam penelitian ini ada dua yaitu: data primer dan data sekunder.

\section{a. Data Primer}

Data primer merupakan sumber data penelitian yang diperoleh secara langsung dari sumber asli (tidak melalui media perantara). Data primer secara khusus dikumpulkan oleh peneliti untuk menjawab pertanyaan penelitian. Hal ini dilakukan oleh peneliti dengan cara terjun langsung ke lapangan atau lokasi yang sudah menjadi obyek penelitian ini. 
Dalam penelitian ini, ada tiga metode yang digunakan peneliti untuk mengumpulkan data primer, yaitu dengan metode observasi, metode wawancara, dan dokumentasi.

b. Data Sekunder

Data sekunder merupakan sumber data yang dianggap penting untuk merampungkan penelitian ini. Data sekunder adalah data yang tidak langsung memberikan data kepada peneliti, misalnya penelitian harus melalui orang lain atau mencari melalui dokumen. Data ini diperoleh berdasarkan catatan-catatan yang berhubungan dengan penelitian, selain itu peneliti menggunakan data yang diperoleh dari internet, seperti jurnal penelitian dan juga berupa bahan-bahan literature lainnya yang dapat menunjang kemudahan dalam proses penelitian ini (Sugiyono, 2015:62).

\section{Teknik Pengumpulan Data}

Teknik pengumpulan data dalam penelitian ini menggunakan dua cara, yaitu: (1) melakukan penelitian lapangan yang akan dilakukan dengan observasi, wawancara dan dokumentasi, (2) membaca sumber-sumber kepustakaan atau menggunakan bahan-bahan tertulis yang dipandang relevan dengan permasalahan yang akan diteliti.

\section{Teknik Analisis Data}

Dalam penelitian ini menggunakan teknik analisis data menurut Miles dan Hubberman, yaitu melalui:

- Collecting: Pengumpulan data berupa katakata sebagai gambaran keadaan yang ada di lapangan.

- Reduction: Memilih secara sistematis meurut kategorinya dengan menggunakan bahasa yang bisa difahami masyarakat secara umum.

- Display: Pemaparan hasil dari wawancara dan catatan lapangan akan dipaparkan secara tertulis sesuai dengan kategorisasi yang telah ditetapkan.

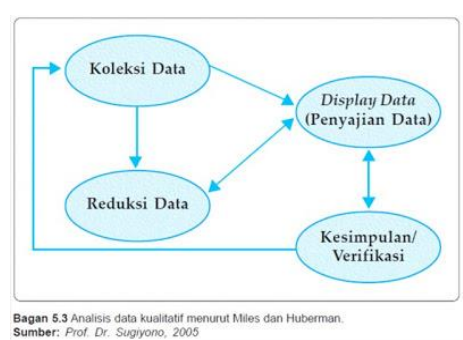

\section{Teknik Penentuan Informan}

Pada penelitian ini, peneliti menggunakan teknik purposive sampling yaitu teknik sampling yang digunakan peneliti jika memiliki pertimbangan-pertimbangan tertentu dalam pengambilan sampelnya (Idrus, 2007:124). Seseorang atau sesuatu yang dijadikan sampel karena peneliti menganggap bahwa seseorang atau sesuatu tersebut memiliki informasi yang diperlukan bagi penelitiannya.

Adapun target pemilihan informan adalah pelaku socio edupreneur, Kepala sekolah dan wali murid di kecamatan Panceng Gresik.

\section{Lokasi dan Waktu Penelitian}

Adapun objek penelitian ini adalah pelaku sosio edupreneur di Kecamatan Panceng Kabupaten Gresik. Penentuan lokasi penelitian dimaksudkan untuk mempermudah dan memperjelas obyek yang menjadi sasaran penelitian, sehingga permasalahan tidak terlalu luas. Adapun waktu penelitian yang akan dilakukan peneliti adalah kurang lebih 6 bulan.

\section{HASIL DAN PEMBAHASAN}

\section{Peran Socio Edupreneur}

\section{a. Peran Aktif}

Adanya sosioedupreneur di beberapa desa di Kecamatan Panceng secara aktif berperan dalam peningkatan motivasi belajar anak serta dapat meningkatkan pemahaman pada anak, dengan pendekatan secara personal pada anak tentunya pelaku socio edupreneur dapat memberikan solusi dengan memberikan pembelajaran lebih detail, sehingga permasalahan anak dengan mata pelajaran dapat terselesaikan, dalam proses belajar pun lebih tenang karena hanya diikuti oleh beberapa anak dan dalam menanamkan nilai-nilai moral lebih mengena pada anak.

Menurut Yuniar, salah satu murid MI Roudlotul Ulum Banyutengah mengatakan bahwa dengan mengikuti les di gurunya sangat membantu dalam meningkatkan kemampuan akan mata pelajaran yang kurang difahaminya ketika 
di sekolah seperti mata pelajaran matematika dan bahasa inggris.

Sedangkan menurut Ardi salah satu siswa SDN 1 Campurejo mengatakan bahwa dengan mengikuti les di Bu Hima sangat membantu dalam memotivasi untuk terus semangat belajar.

Dari bebrapa pendapat tersebit dapat disimpulkan bahwa adanya socio edupreneur secara aktif ikut perperan dalam memotivasi dan meningkatan skill, knowledge serta attitude pada anak.

\section{b. Peran Partisipatif}

Bagi lembaga pendidikan (sekolah) dengan danya sosioedupreneur di beberapa desa di Kecamatan Panceng sangat membantu para guru dalam mengajar siswanya. Tanggapan positif kerap kali terlontar dari mulut guru-guru untuk mengapresiasi adanya jasa les yang ada disekitarnya.

Nurul Wakhidatul Ummah, Kepala Sekolah SMPM 13 Campurejo mengatakan" Bahwa adanya sosioedupreneur membantu peran guru dalam meneragkan dan mengajarkan materi yang masih kurang dipahami oleh para siswa saat di sekolah, sangat dibutuhkan orang-orang yang ikhlas dalam mengamalkan ilmu dan mengabdi kepada masyarakat di desanya sendiri, menyediakan wadah agar siswa mampu belajar bersama dengan biaya yang ringan, yang secara tidak langsung hal tersebut menambah semangat siswa untuk belajar bersama dengan suasana diluar sekolah, membantu peran guru dan orangtua dalam memberikan ilmu".

Pemahaman akan pentingnya pendidikan di desa sangat diperlukan agar anak di desa juga mampu menjadi orang yang berhasil dikemudian hari yang mampu menjadi mobilitas dikeluargannya. Kurangnya kesadaran masyarakat akan pentingnya pendidikan dan juga les tambahan untuk menambah anaknya agar siap berkompetisi kelak serta lebih paham dengan mata pelajaran yang dipelajari.

Perbedaan kemapuan antara siswa yang mengikuti les tambahan dengan yang tidak pun pasti akan berbeda. Siswa yang mengikuti les tambahan cenderung lebih percaya diri saat menjawab pertanyaan, lebih mudah memahami saat mengulas materi atau mempelajari materi baru disekolah karena sebelumnya sudah dipelajari di tempat les, serta lebih aktif selama pembelajaran di kelas berlangsung.

Bagi orang tua keberadaan socio eduprenenur secara langsung ikut perpantisipasi dalam Setiap orangtua pasti menginginkan yang terbaik untuk masa depan anaknya, banyak cara yang dilakukan orangtua bagi anaknya, salah satunya yakni mendapatkan pendidikan yang layak dan terbaik. Upaya menanamkan pendidikan bagi anaknya dengan menyekolahkan dilembaga pendidikan yang ada di lingkungan sekitar.

Umi Syafaatin, salah satu orangtua siswa yang mengikuti les tambahan di salah satu bimbingan belajar di desa Panceng, mengatakan "Sosioedupreneur sangat membantu orangtua dalam mengajari anaknya untuk belajar, terkadang anak bosan diajari oleh orangtua sendiri yang kebanyakan marah saat anaknya tidak bisa mengerjakan pekerjaan rumahnya, sehingga adanya les sangat membantu, karena anak akan lebih menurut kepada guru dari pada orangtuannya”.

Orangtua terkadang terlalu sibuk dengan pekerjaan masing-masing sehingga waktu untuk menemani anaknya belajar kurang dan saat capek akan cenderung memarahi anak jika anaknya tidak bisa memahami dan menjawab materi yang diajarkan di sekolah.adanya les tambahan ini sangat membantu mengatasi hal tersebut. Sulitnya orangtua mengajar belajar anaknya terbantu dengan peran guru kedua di les yang menunjang pembelajaran yang belum dipahami anaknya disekolah.

Biaya yang ringan yang ditawarkan dan sedikitnya bimbingan belajar yang tersedia di desa membuat orangtua berbondong-bondong menitipkan anaknya untuk mengikuti les tambahan tersebut, dengan tujuan agar anaknya lebih pag]ham dan waktu di luar jam sekolah tidak hanya dihabiskan anaknya untuk bermain di luar rumah dan lupa akan kewajibannya sebagai siswa yakni belajar. 
Jumlah sosioedupreneur diharapkan terus meningkat agar peran dalam memberi tambahan pengajaran materi dan mengatasi kesulitan akan pekerjaan rumah dapat menyeluruh dan dirasakan oleh anak-anak diseluruh desa yang ada di Kecamatan Panceng.

\section{Kendala Sosioedupreneur}

Walaupun Socio Edupreneur mempunyai peran yang begitu penting dalam peningkatan kualitas pendidikan tetapi pada prakteknya banyak sekali kendala yang dihadapi oleh pelaku socio edupreneur, adapun kendala-kendala yang dihadapi yaitu:

\section{a. Faktor Tempat}

Tempat merupakan factor yang sangat berpengaruh dalam memulai suatu usaha. Seringkali tempat tidak dianggap terlalu penting dan dipandang remeh dalam memulai usaha, padahal tempat (lokasi usaha) merupakan factor pendukung utama dalam menjalankan usaha, tempat menjadi akses terpenting untuk dijangkau oleh para konsumennya. Dalam penentuan tempat (lokasi) ini harus mempertimbangkan beberapa aspek antara lain: aspek keamanan, aspek lingkungan, kompetisi, akses lalu lintas, budget,tempat, design, dan lain-lain.

Melihat dari hasil wawancara guru les (usaha les) di beberapa desa di Kecamatan Panceng, terkait masalah tempat (lokasi) sebagian besar tempat yang digunakan adalah rumah sendiri. Tentunya hal tersebut masih bersifat konvensional dan tidak mempedulikan aspek-aspek penentuan lokasi usaha. Dilain sisi, tempat yang digunakan juga tidak dapat menampung banyak siswa yang belajar didalamnya, sehingga kuota penerimaan siswa pun terbatas. Jika dipaksakan terlalu banyak siswa didalmnya maka akan membuat siswa tidak nyaman dan guru tidak dapat maksimal dalam menyampaikan materi, namun jika hanya menerima siswa yang terbatas akan banyak siswa yang tertolak dan merasa kecewa.

\section{b. Faktor fasilitas dan sistem}

Bicara akan factor fasilitas dan sistem pembelajaran, factor ini tidak kalah penting dengan factor-faktor lainnya. Factor yang menentukan arah dan kenyamanan dalam kelangsungan pembelajaran. Jika tidak tersedia dan tersusun dengan baik maka akan berpengaruh kepada siswa dan guru dalam menyampaikan serta menangkap materi.

Dari hasil wawancara, faktor ini menjadi permasalahan yang sangat kompleks, dimana fasilitas yang tersedia dalam usaha bimbingan yang ada sangat terbatas hanya papan tulis,dan meja. Tidak ada fasilitas yang memadai seperti projector, pendingin ruangan, modul dan sebagainya. Hal tersebut berpengaruh terhadap sistem pembelajaran yang dilakukan oleh guru yang tidak dapat maksimal, metode yang diajarkan monoton sama, dan cenderung membuat siswa bosan.

Sistem pembelajaran yang diberikan guru kepada siswa tidak maksimal, dikarenakan sistem pembelajaran yang digunakan sesuai dengan jadwal siswa disekolah. Setiap les siswa menerima dan belajar semua pelajaran yang akan diajarkan besoknya sehingga siswa tidak dapat menangkap materi dengan baik, begitu juga guru dalam menyampaikan materi tentunya harus ekstra menjelaskan agar semua mata pelajaran tersampaikan.

Daya pikir dan kemampuan materi tiap siswa yang berbeda-beda dan tidak adanya modul pembelajaran khusus untuk membantu materi membuat siswa sulit menagkap semua penjelasan guru, tak ayal yang didapatkan siswa hanya sedikit dan terkadang mereka les hanya untuk membantu mengerjakan pekerjaan rumah para siswa.

\section{c. Faktor Terbatasnya Tentor}

Tentor adalah pembimbing yang mengajarkan hal kecil kepada kita, namun jika yang kita dapat kita kembangkan maka akan memiliki banyak nilai dan menambah pengetahuan kita. Tentor merupakan aspek utama dalam memulai usaha bimbingan belajar, karena tentunya tanpa tentor tidak akan berlangsung sebuah pembelajaran 
dalam arti lain tidak akan ada yang menjadi pengajar di dalam kelas.

Dalam hasil wawancara, banyak usaha bimbingan belajar yang mengeluhkan factor ini, terbatasnya tentor membuat usaha mereka terhambat untuk membuka penerimaan siswa baru di bimbingan belajar mereka. Dimana saat akan menambah siswa, perlu juga untuk menambah tentor, agar pembelajaran dan penyampaian materi dapat tersampaikan dengan maksimal kepada para siswa.

Tentor yang terbatas di desa dikarenakan sedikitnya orang yang mau mengajar di desa karena beberapa factor seperti gaji yang rendah, sulitnya mengajari dan menghadapi siswa dengan beragam kemampuan daya pikir, metode pembelajaran yang masih sederhana, serta tunututan tanggungjawab yang besar. Sehingga banyak usaha bimbingan belajar yang hanya memiliki satu tentor yakni pemilik usaha les itu sendiri.

\section{d. Faktor Waktu}

Guru merupakan salah astu profesi dengan tuntutan beradaptasi yang tinggi, menghadapi siswa dengan latar belakang dan karakter yang berbeda, mengharuskan para guru (tentor) mengubah strategi pembelajaran yang akan dilakukan. Dilain sisi kesibukan mereka tidak hanya sebagai pengajar di bimbingan belajar saja, melainkan juga menjadi ibu rumah tangga, merawat rumah, mengurus pekerjaan lain, serta mengajari anaknya sendiri.

Waktu yang tersedia dalam bimbingan belajar pun terbatas hanya satu hingga dua jam saja untuk siswa belajar dan guru menyampaikan materi. Tuntutan untuk menyampaikan materi sesuai jadwal di sekolah yang setiap harinya bisa empat hingga lima mata pelajaran yang harus diajarkan kepada siswa di tempat les yang hanya dua jam membuat tentor merasa kesulitan dan siswa pun pusing akan materi yang harus dipelajari secara bersamaan.

Banyak siswa tidak hanya mengikuti satu les saja, karena orangtua merasa anaknya kurang dalam memahami beberapa pelajaran tang dirasa masih butuh bantuan guru untuk menerangkan kepada anaknya, alasan waktu juga menjadi alasan untuk mengikuti lebih dari satu les.

\section{Solusi Kendala Socio edupreneur}

\section{a. Faktor Tempat}

Kendala tempat menjadi salah satu factor yang dikeluhkan saat memulai usaha sosioedupreneur, namun dari kendala yang ada dapat muncul beberapa solusi yang dapat dilakukan pelaku usaha sosioedupreneur untuk mengatasi kendala factor tempat tersebut diantarannya:

- Di awal memulai usaha dapat dilakukan di rumah, sambil mengumpulkan uang dari infaq yang diberikan siswa untuk menyewa tempat yang lebih luas.

- Mengatur tata letak ruangan rumah yang ditempati agar terlihat luas dan membuat nyaman saat pembelajaran.

- Membuat tanda atau petunjuk arah untuk memudahkan pengguna jasa dalam mencari saat membutuhkan jasa bimbingan belajar.

- Memperkirakan ruangan yang digunakan dapat menampung berapa jumlah siswa dengan suasana yang nyaman.

\section{b. Faktor Fasilitas dan Media Pembelajaran}

Fasilitas dan media pembelajaran adalah hal penting bagi kenyamanan saat pembelajaran di kelas berlangsung. Solusi yang dapat dilakukan untuk mengatasi kendala tersebut antara lain:

- Membuat modul pembelajaran sebagai media yang dapat digunakan saat pembelajaran.

- Menyusun jadwal les agar mata pelajaran yang diajarkan dapat dipahami secara maksimal oleh para siswa.

- Seminggu sekali melakukan metode yang berbeda seperti: outdoor, games edukasi, dan sebagainya.

- Fasilitas terbatas dapat dioptimalkan dengan penataan ruang dan design ruang yang nyaman sehingga siswa merasa nyaman saat pembelajaran berlangsung dan tidak mudah bosan. 


\section{c. Faktor Kurangya Tentor}

Kurangnya tentor memang menjadi suatu permasalahan yang cukup penting dalam usaha jasa bimbingan belajar, kurangnya tentor membuat kurangnya variasi pengajar yang ada sehingga kurangnya inovasi pembelajaran yang muncul. Namun hal tersebut juga memiliki solusi yang dapat dilakukan untuk memberikan penangganan dari kendala tersebut, diantarannya yakni:

- Merekrut siswa lulusan SMA atau mahasiswa yang ada di sekitar les tersebut untuk menjadi tentor walaupun tidak tetap.

- Mengajak guru / orang yang berkenan dan mau untuk menjadi tentor di bimbingan belajar.

- Walaupun hanya satu tentor namun dapat divariasi dengan menayangkan tentor (video) pembelajaran yang sesuai.

\section{d. Faktor Terbatasnya Waktu}

Waktu yang hanya beberapa jam untuk melakukan kegiatan bimbingan belajar menyebabkan tidak maksimalnya pembelajaran yang diberikan kepada siswa. Banyaknya kegiatan dalam dua puluh empat jam terkadang membuat capek dan malas saat belajar apalagi setelah otak terkuras memahami materi disekolah dan dituntut untuk memahami materi tambahan di bimbingan belajar. Kendala akan factor waktu dapat diatasi dengan beberapa factor antara lain:

- Menyusun agenda kegiatan agar dapat termanage dengan baik.

- Mengatur hari-hari tertentu untuk kegiatan les tambahan sehingga tidak setiap hari dalam satu minggu.

- Memfokuskan untuk beberapa mata pelajaran saya yang diajarkan agar dapat maksimal.

Membuat jadwal (susunan waktu) pembelajaran, seperti berapa menit untuk menjelaskan, mengerjakaan soal-soal, dan mengerjakan pekerjaan rumah.

\section{KESIMPULAN}

Dari pembahasan tersebut dapat disimpulkan bahwa keberadaan socio edupreneur mempunyai beberapa peran yaitu peran aktif dan patisipatif. Socio edupreneur secara aktif berperan dalam memotivasi anak dalam belajar dan secara aktif meningkatkan skill, knowledg dan attitude pada anak. Sedangkan pada lembaga pendidikan (sekolah), socio edupreneur ikut berpartisipasi dalam membantu proses belajar mengajar di kelas dan bagi orang tua sangat membantu dalam melaksanakan kewajibannya dalam mendidik anak.

Keterbasan orang tua dalam membiayai pendidikan anak, keterbatanan kemampuan dalam mendidik anak, serta keterbatasan guru dalam mengajar dengan jumlah siswa yang begitu banyak dalam kelas, menjadikan Socio edupreneur sebagai solusi dalam peningkatan kualitas pendidikan anak, yang tentu saja akan berdampak pada kualitas pendidikan pada sebuah lembaga dan pada akhirnya dapat meningkatkan kualitas pendidikan di Indonesia.

Adapun beberapa faktor kendala yang dihadapi oleh pelaku socio edupreneur adalah: faktor tempat, faktor fasilitas dan sistem pembelajaran. Faktor terbatasnya tentor, serta faktor waktu..

\section{SARAN}

Penelitian ini diberi saran :

1. Mengingat begitu pentingnya peran socio edupreneur dalam peningkatan kualitas pendidikan siswa pada lembaga pendidikan hendaknya ada kerja sama yang baik antara pihak lembaga dengan pelaku socio edupreneur dengan harapan bisa bertukar data perkembangan siswa di sebuah lembaga dan saling memberikan solusi.

2. Orang tua diharapkan bisa membantu dalam melakukan pengawasan terhadap anak ketika di rumah karena waktu terbanyak anak adalah ketika berada di rumah, dan hendaknya orang tua ikut memikirkan kesejahteraan pelaku socio edupreneur, karena dalam prakteknya tidak memungut biaya, yang didapat hanya uang seikhlasnya (udu/umplungan) dan rata-rata setiap anak hanya memberikan uang sebesar 2 ribu rupiah.

3. Bagi pelaku socio edupreneur hendaknya membuka usaha lain bisa memberikan pemasukan untuk kesejahteraannya dan 
pengadaan sarana dan prasarana dalam proses pembelajaran.

\section{DAFTAR PUSTAKA}

Ahmadi, Abu. 2009. Psikologi Sosial. Jakarta: Rineka Cipta.

Bungin, Burhan. 2003. Analisis Data Penelitian Kualitatif . Jakarta: PT Raja Grafindo Persada

Depdiknas .2003. Undang-undang RI No.20 tahun 2003.tentang sistem pendidikan nasional.

Faisal S. (1995) Format-Format Penelitian Sosial, Dasar-Dasar dan Aplikasi. Cetakan Ketiga. Jakarta: PT Prenkalindo.

Idrus, Muhammad. (2007). Metode Penelitian Ilmu-Ilmu Sosial (Pendekatan Kualitatif dan Kuantitatif).Yogyakarta :UII Press Yogyakarta

Moleong, Lexy. J. 2016. Metodologi Penelitian Kualitatif Edisi Revisi. Bandung: PT. Remaja Rosdakarya.

Sugiyono. 2015. Metode Penelitian Pendidikan (Pendekatan Kuantitatif, Kualitatif dan R\&D). Penerbit CV. Alfabeta: Bandung.

Soekanto, Soerjono, 2012. Sosiologi:Suatu Pengantar, Jakarta, Penerbit Rajawali Pers.

Suryana. (2003). Kewirausahan: Pedoman praktis, kiat dan proses menuju sukses (Edisi Revisi). Jakarta: Salemba Empat.

Tarmudji, Tarsis.,2006. Prinsip-Prinsip Kewirausahaan, Liberti, Yogyakarta 